\title{
Effects of Real Exchange Rate on Trade Balance in Cote d'Ivoire: Evidence from Threshold Nonlinear ARDL Model
}

\author{
Yaya Keho \\ Ecole Nationale Supérieure de Statistique et d'Economie Appliquée (ENSEA) Abidjan, Abidjan, Côte d'Ivoire \\ Email: ayakeho@yahoo.fr
}

How to cite this paper: Keho, Y. (2021). Effects of Real Exchange Rate on Trade Balance in Cote d'Ivoire: Evidence from Threshold Nonlinear ARDL Model. Theoretical Economics Letters, 11, 507-521.

https://doi.org/10.4236/tel.2021.113034

Received: April 27, 2021

Accepted: June 14, 2021

Published: June 17, 2021

Copyright $\odot 2021$ by author(s) and Scientific Research Publishing Inc. This work is licensed under the Creative Commons Attribution International License (CC BY 4.0).

http://creativecommons.org/licenses/by/4.0/

\begin{abstract}
The objective of this paper is to shed new light on the nonlinear relationship between real exchange rate changes and trade balance in Cote d'Ivoire. In examining this issue, previous studies have relied on the nonlinear autoregressive distributed lag model developed by Shin et al. (2014) where real exchange rate is decomposed into partial sum of positive and negative changes. They fail to examine the response of the trade balance to extreme changes in the real exchange rate. In order to investigate possible sign and size-dependence in the response of the trade balance to exchange rate, this study uses multiple threshold nonlinear ARDL modeling. The approach is implemented using annual data covering the period 1975-2017. The results reveal that the effects of changes in real exchange rate are asymmetric in both time horizons. More specifically, real exchange rate appreciations deteriorate the trade balance while real depreciations improve it. Further, the effect of large depreciations is higher when compared with large appreciations.
\end{abstract}

\section{Keywords}

Nonlinear ARDL, Asymmetry, The Trade Balance, The Exchange Rate

\section{Introduction}

The relationship between the exchange rate and the trade balance is a subject of intense research in international economics, especially since 1973 when Magee (1973) introduced the concept of the J-curve effect. According to this concept, a real devaluation of domestic currency leads to an initial deterioration of the trade balance, subsequently followed by an improvement. This suggests that the effect of real depreciation of exchange rate on trade balance is negative in the short-run and becomes positive in the long-run. The study by Magee (1973) ar- 
gued that contracts negotiated before the devaluation of the domestic currency may be responsible for the deterioration of the trade balance in the short-run. Theoretically, devaluation improves the trade balance through two channels. Firstly, it makes the domestic goods cheaper for the foreign trading partners, thus increasing exports. Secondly, it brings about a decrease in imports since imports become relatively more expensive. Understanding the extent to which real exchange rate changes are passed through to trade balance is an important issue from balance payment perspective.

Until recently, the existing empirical research assumed a linear relationship between real exchange rate and trade balance. The evidence from this literature is mixed and conflicting. Some studies found that depreciation of real exchange rate has a significant improving effect on trade balance (Baharumshah, 2001; Bahmani-Oskooee, 2001; Boyd et al., 2001; Kale, 2001; Lal \& Lowinger, 2002; Musila \& Newark, 2003; Yol \& Baharumshah, 2007; Igue \& Ogunleye, 2014; Anning et al., 2015; Caporale et al., 2015; Ogbonna, 2016; Hunegnaw \& Kim, 2017; Ousseini et al., 2017; Sokeng Dongfack \& Ouyang, 2019; Yazgan \& Ozturk, 2019; Keho, 2021a), while others reported that depreciation worsens trade balance (Onafowora, 2003; Adeniyi et al., 2011; Genemo, 2017). Still, others failed to establish any significant relationship between the two variables (Hatemi-J \& Irandoust, 2015; Duasa, 2007; Loto, 2011; Akpansung \& Babalola 2013; Shawa \& Shen, 2013; Meniago \& Eita, 2017; Kamugisha \& Assoua, 2020). Such conflicting findings point to the need for further examination of the relationship between exchange rate and trade balance.

It is possible that the failure to appropriately establish a significant relationship between real exchange rate and trade balance may be as a result of the assumption of symmetry. Recently, the economic literature developed some arguments that make the hypothesis of linearity unrealistic. According to this strand of literature, trade balance may respond differently to exchange rate appreciation and depreciation. This asymmetry in exchange rate pass-through to trade balance could be attributed to price rigidity, that is prices are more sticky downwards than upwards. There is evidence that trade goods prices respond to exchange rate changes asymmetrically (Karoro et al., 2009; Bussière, 2013). Others sources of asymmetry include adjustment costs, quantity restrictions, the presence of market power, government interventions, fixed contracting and negotiating terms of exporters (Magee, 1973; Bussière, 2013). In such a context, results from linear models may be misleading.

A number of empirical researches employed the nonlinear ARDL approach introduced by Shin et al. (2014) to re-examine the asymmetric response of trade balance to real exchange rate changes. For instance, Iyke and Ho (2017) examined the case of Ghana and found that real depreciation of the exchange rate improves the trade balance in the long-run, while real appreciation does not have any impact on the trade balance. Relying on the nonlinear ARDL model, Bahmani-Oskooee \& Fariditavana $(2015,2016)$ and Arize et al., (2017) also confirmed asymmetric effects of exchange rate changes on the trade balance. Study 
by Akoto and Sakyi (2019) investigated the determinants of trade balance in Ghana. They found that depreciation of the Ghana cedi does not improve its trade balance. Bahmani-Oskooee, M. and Arize, A. C. (2019) analyzed the bilateral trade balance of the US with each of her 20 trading partners from Africa. They found support for the J-curve effect in eight partners. Furthermore, there are short-run asymmetric effects of exchange rate changes in almost all countries and significant long-run asymmetric effects in half of the partners. Bahmani-Oskooee, M. and Baek, J. (2019) studied the case of Korean bilateral trade with her 14 partners. They came out with the result that in most cases, the exchange rate changes have short-run and long-run asymmetric effects on the bilateral trade balance. Bahmani-Oskooee, M., Bose, N., and Zhang, Y. (2019) analyzed the trade balance between the US and China at the commodity level. Considering 97 commodities, they found significant short-run asymmetric effects for two-third of the commodities and significant long-run asymmetry for one-third of the commodities. Bahmani-Oskooee, M., and Arize, A. C. (2020) examined the case of 13 African countries and found asymmetric effects in many of the countries. Bahmani-Oskooee, M., and Fariditavana, H. (2020) focused on the bilateral trade balance of the U.S. with Canada for 161 industries. They found asymmetric short-run effects in all industries and significant long-run asymmetric effects in 62 industries. Bahmani-Oskooee, M. and Gelan, A. (2020) considered the bilateral trade balance of South Africa with the U.S. for 25 industries. They found short-run asymmetric effects in 19 industries, which last into long-run asymmetric effects in 14 industries. Keho (2021b) investigated the trade balance of Nigeria and found that positive and negative shocks in the exchange rate are associated with a negative impact on the trade balance, but only the effects of positive shocks are significant. Finally, in a study of Cote d'Ivoire, Nathaniel (2020) showed that the trade balance responds stronger to negative shocks in the real exchange rate than to positive shocks in the long-run.

The nonlinear ARDL approach of (Shin et al., 2014) filters appreciations from depreciations and evaluates their separate effects on the trade balance. This implies a zero threshold effect depending on the direction of the change in exchange rate. Studies with respect to size of change in exchange rate are quite scanty. This study aims to strengthen the empirical literature by investigating the effects of exchange rate non-linearity on the trade balance in Cote d'Ivoire. In addition to investigating the magnitude and direction of the effect of exchange rate on the trade balance, it analyses the size effect of a change in the real exchange rate. This is the first paper that applies multiple threshold nonlinear ARDL model to test the short and long-run asymmetric effects of real exchange rate on the trade balance in Cote d'Ivoire. It is our belief that the results of this study will contribute invaluably to the existing literature on the effects of exchange rate on the trade balance in African countries.

The rest of the paper is organized as follows. Section 2 describes the econometric methodology and the data used in the study. The results are presented and discussed in Section 3. Finally, Section 4 provides some concluding remarks. 


\section{Model, Data and Methodology}

\subsection{Empirical Model}

The objective of this study is to ascertain the effects of real exchange rate on the trade balance and to test whether real depreciation and appreciation of currency have the same effect on the trade balance. Following existing studies, the empirical model is specified as follows:

$$
\ln \mathrm{TB}_{t}=\beta_{0}+\beta_{1} \ln \mathrm{Y}_{t}+\beta_{2} \ln \mathrm{YF}_{t}+\beta_{3} \ln \mathrm{RER}_{t}+\beta_{4} \mathrm{D} 94_{t}+\mu_{t}
$$

where:

- TB is the trade balance on goods and services defined as the ratio of exports to imports;

- Y is domestic real GDP used as a proxy for domestic income;

- YF is world real GDP used as a proxy for foreign income;

- RER is the real effective exchange rate defined in a way that a decline (increase) reflects a real depreciation (appreciation) of the domestic currency;

- D94 is a dummy variable that takes the value of zero for the period before 1994, the year of the CFA franc devaluation, and one otherwise;

- $\quad \mu_{t}$ is an error term assumed to be a white-noise process.

As far as the expected sign of each coefficient is concerned, the estimates of $\beta_{1}$ and $\beta_{2}$ can either be positive or negative depending upon whether income is spent on domestic goods or foreign goods. The coefficient $\beta_{1}$ is negative if higher levels of domestic income increase the demand for imports. Similarly, the coefficient $\beta_{2}$ is positive suggesting that higher levels of foreign income increase the demand for domestic goods by the rest of the world. Finally, a real depreciation of the real exchange rate is expected to improve the trade balance. Therefore, the coefficient $\beta_{3}$ is expected to be negative.

\subsection{Data Description}

The study uses annual data covering the period from 1975 to 2017. The variables under study are trade balance defined as the ratio of exports to imports, domestic real GDP in constant US dollar as a proxy for foreign income, world real GDP in constant US dollar as a proxy for foreign income, and real effective exchange rate. Data on the trade balance, domestic real GDP, and world real GDP were extracted from the World Bank's World Development Indicators database. Data on the real effective exchange rate were retrieved from the Central Bank of West African States (BCEAO). The real effective exchange rate variable is such that an increase (decrease) signifies a real appreciation (depreciation) of the domestic currency. For the empirical analysis, all variables were transformed into natural logarithm. From a statistical point of view, the logarithmic transformation mitigates fluctuations of individual variables increasing the likelihood of stationarity after first differencing. From an economic point of view, the logarithmic transformation allows the first differences of the variables to be interpreted as growth rates and coefficients in terms of elasticity. 
Figure 1 portrays the trends of the trade balance and the real effective exchange rate over the period 1975-2017. We observe that both variables exhibit considerable fluctuations over the sample period. The real effective exchange rate has been appreciating after the devaluation of the CFA franc in January 1994. Between 1994 and 2009, the real effective exchange rate appreciated by about $24 \%$, and started to depreciate from 2009. It is worth mentioning that structurally low inflation rate over the post-devaluation period helps limit the appreciation of the real effective exchange rate, which is still trading $25 \%$ below the 1993 level.

Table 1 shows some descriptive statistics and correlations of the variables. It can be observed that trade balance averages 4.746 and ranges from 4.421 to 4.986. It can be seen that domestic and foreign income exhibit the highest variability over the period, as indicated by their respective standard deviations, while real effective exchange rate and trade balance are the least volatile. The Jarque-Bera statistic suggests that all the variables under study are normally distributed. The correlation matrix indicates a positive and significant relationship between the trade balance and foreign income. A negative and significant relationship exists between the trade balance and the real exchange rate whereas foreign income is positively and significantly associated with the trade balance. The correlation matrix also reveals a problem of collinearity between domestic income and foreign income, with a correlation value of 0.913 . Hence, the foreign income variable was left out of the empirical analysis.

Table 1. Descriptive statistics and correlation matrix. (a) Summary statistics; (b) Correlation matrix.

(a)

\begin{tabular}{ccccc}
\hline Variables & $\operatorname{lnTB}$ & $\operatorname{lnY}$ & $\operatorname{lnYF}$ & $\operatorname{lnRER}$ \\
\hline Mean & 4.746 & 23.755 & 31.415 & 4.662 \\
Median & 4.746 & 23.747 & 31.406 & 4.6125 \\
Maximum & 4.986 & 24.399 & 32.015 & 4.911 \\
Minimum & 4.421 & 23.326 & 30.772 & 4.427 \\
Std. dev. & 0.127 & 0.237 & 0.367 & 0.122 \\
Skewness & -0.410 & 0.868 & -0.032 & 0.477 \\
Kurtosis & 3.479 & 3.463 & 1.783 & 2.095 \\
Jarque-Bera & 1.620 & 5.794 & 2.660 & 3.098 \\
Probability & 0.444 & 0.055 & 0.264 & 0.212 \\
\hline
\end{tabular}

(b)

\begin{tabular}{ccccc}
\hline Variables & $\ln \mathrm{TB}$ & $\ln \mathrm{ln}$ & $\ln \mathrm{F}$ & $\ln \mathrm{RER}$ \\
\hline $\ln \mathrm{TB}$ & 1.000 & & & \\
$\ln \mathrm{Y}$ & 0.101 & 1.00 & & \\
$\ln \mathrm{FF}$ & $0.308^{*}$ & $0.913^{*}$ & 1.000 & \\
$\ln \mathrm{PER}$ & $-0.588^{*}$ & $-0.499^{*}$ & $-0.569^{*}$ & 1.000 \\
\hline
\end{tabular}

Note: ${ }^{*}$ and ${ }^{* *}$ indicate statistical significance at the $5 \%$ and $10 \%$ levels, respectively. 

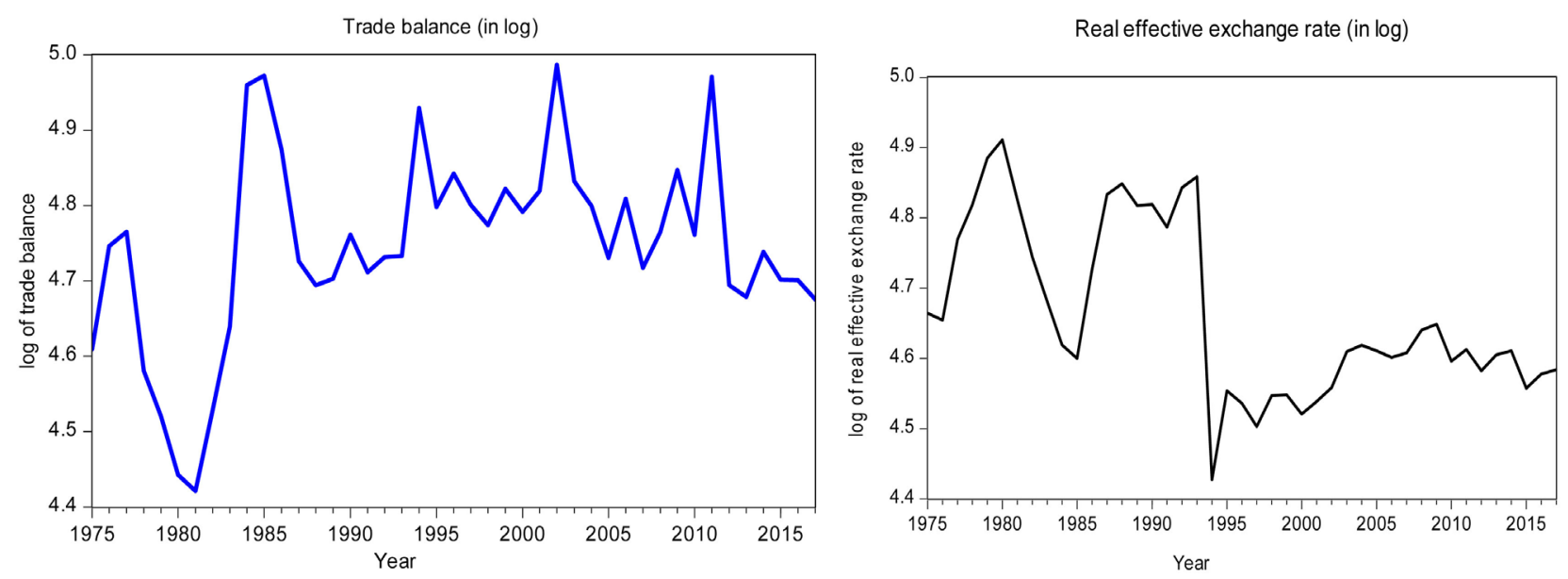

Figure 1. Trade balance and real exchange rate (in log) over the period 1975-2017.

\subsection{Econometric Methodology}

The methodology of the empirical analysis proceeds as follows. As a first step, we test for the order of integration of the series by using unit root tests. Second, in order to avoid spurious estimation we must establish that the variables are cointegrated. The evidence from existing empirical studies suggest that macroeconomic time series are either integrated of order zero or one. A cointegration method that allows variables to be a combination of $\mathrm{I}(0)$ and $\mathrm{I}(1)$ was proposed by Pesaran et al. (2001) as bounds testing approach to cointegration. This approach is relatively more efficient in small sample data sizes in which the order of integration is not well known or may not be necessarily the same for all variables under study. It has shown to provide consistent estimates of the long-run parameters in the presence of endogenous regressors (Inder, 1993; Gonzalo, 1994).

The bounds test for cointegration involves estimating by ordinary least square the following ARDL model:

$$
\ln \mathrm{TB}_{t}=\alpha+\gamma \mathrm{D} 94_{t}+\sum_{j=1}^{m} \phi_{0 j} \ln \mathrm{TB}_{t-j}+\sum_{j=0}^{n} \phi_{1 j} \ln \mathrm{Y}_{t-j}+\sum_{j=0}^{q} \phi_{2 j} \ln \mathrm{RER}_{t-j}+\mu_{t}
$$

After reparametrisation, Equation (2) can be rewritten in the unrestricted error-correction form:

$$
\begin{aligned}
\Delta \ln \mathrm{TB}_{t}= & \alpha+\delta_{0} \ln \mathrm{TB}_{t-1}+\delta_{1} \ln \mathrm{Y}_{t-1}+\delta_{2} \ln \mathrm{RER}_{t-1}+\gamma D 94_{t} \\
& +\sum_{j=1}^{m-1} \phi_{0 j} \Delta \ln \mathrm{TB}_{t-j}+\sum_{j=0}^{n-1} \phi_{1 j} \Delta \ln \mathrm{Y}_{t-j}+\sum_{j=0}^{q-1} \phi_{2 j} \Delta \ln \mathrm{RER}_{t-j}+\mu_{t}
\end{aligned}
$$

A main feature of Equation (3) is that appreciation and depreciation of real exchange rate have the same effect on the trade balance. Accordingly, it does not allow potential asymmetry or nonlinearity in the effect of exchange rate on the trade balance. As mentioned before, this needs not be the case if imports and exports respond to exchange rate changes in an asymmetric manner. Negative shocks in the real exchange rate could impact on the trade balance at different rates compared to positive shocks. 
Recently Shin et al. (2014) developed a nonlinear version of the standard ARDL model by decomposing the non-linear variable into positive and negative variations. This approach implies one-threshold model with two sub-variables of the real exchange rate, splitting depreciations from appreciations. This decomposition provides results that may be easily interpreted. However, the use of a zero threshold may introduce a finite sample problem in one regime (Davies, 1987). In addition, it is possible that the trade balance responds differently when facing small or large changes in the exchange rate. In the absence of a clear guideline to measure large and small changes, we can set the threshold value equal to one standard deviation of the first difference of the exchange rate. Another candidate of the threshold could be the mean value of the exchange rate growth rate. We can also use the quantiles of the real exchange rate growth $(\triangle \operatorname{lnRER})$ and define large change as any change that is greater than the $75^{\text {th }}$ quantile, while a small change is below the $25^{\text {th }}$ quantile. In this study, we borrow the concept of partial sum from econometric literature and use a more general approach determining the threshold values endogenously. Accordingly, the partial sum series are constructed as follows:

$$
\begin{aligned}
& \mathrm{LPOS}_{t}=\sum_{i=1}^{t} \Delta \ln \mathrm{RER}_{i} \times I_{\left(\Delta \ln \mathrm{RER}_{i}>s_{2}\right)} \\
& \mathrm{MED}_{t}=\sum_{i=1}^{t} \Delta \ln \mathrm{RER}_{i} \times I_{\left(s_{1} \leq \Delta \ln _{\mathrm{nER}} \leq s_{2}\right)} \\
& \mathrm{LNEG}_{t}=\sum_{i=1}^{t} \Delta \ln \mathrm{RER}_{i} \times I_{\left(\Delta \ln \mathrm{RER}_{i}<s_{1}\right)}
\end{aligned}
$$

where $I_{(\cdot)}$ is an indicator function taking the value one if the condition contained in the brackets is satisfied and zero otherwise, $s_{1}$ and $s_{2}$ are the threshold values such as $s_{1} \leq s_{2}$. Equation (4) selects large positive changes (i.e. large appreciations) in the real exchange rate. Equation (6) chooses large negative changes (i.e. large depreciations) in the real exchange rate. Finally, Equation (5) contains the intermediate variations of the real exchange rate between $s_{1}$ and $s_{2}$ (i.e. small exchange rate changes).

Replacing lnRER with LPOS, MED and LNEG variables into Equation (3), gives the following threshold asymmetric error-correction model:

$$
\begin{aligned}
\Delta \ln \mathrm{TB}_{t}= & \alpha+\delta_{0} \ln \mathrm{TB}_{t-1}+\delta_{1} \ln \mathrm{Y}_{t-1}+\delta_{2} \mathrm{LPOS}_{t-1}+\delta_{3} \mathrm{MED}_{t-1} \\
& +\delta_{4} \mathrm{LNEG}_{t-1}+\gamma \mathrm{D}_{t}+\sum_{j=1}^{m-1} \phi_{0 j} \Delta \ln \mathrm{TB}_{t-j}+\sum_{j=0}^{n-1} \phi_{1 j} \Delta \ln \mathrm{Y}_{t-j} \\
& +\sum_{j=0}^{q-1}\left(\phi_{2 j} \Delta \mathrm{LPOS}_{t-j}+\phi_{3 j} \Delta \mathrm{MED}_{t-j}+\phi_{4 j} \Delta \mathrm{LNEG}_{t-j}\right)+\mu_{t}
\end{aligned}
$$

This specification allows us to investigate possible sign and size-dependence in the response of the trade balance to the real exchange rate changes. The presence of a long-run relationship between the variables is tested by restricting the coefficients of lagged level variables equal to zero, that is, $\mathrm{H}_{0}: \delta_{0}=\delta_{1}=\delta_{2}=\delta_{3}=$ $\delta_{4}=0$. This hypothesis is tested using $F$-test. The critical values are reported in 
(Pesaran et al., 2001). The lower critical bound assumes all the variables to be stationary, i.e. I(0), whereas the upper critical bound assumes all the variables to be stationary at first difference, i.e. I(1). If the computed F-statistic is higher than the upper critical value, then the null hypothesis of the absence of long-run relationship among the variables is rejected. If the F-statistic is below the lower critical value, then the null hypothesis cannot be rejected. The result is inconclusive if the computed F-statistic falls within the upper and lower bound values. Shin, et al. (2014) argued that due to dependency between partial sum variables, LPOS, MED, and LNEG should be treated as one variable and consequently assume that there are two (and not four) exogenous variables. The implication is that the same critical values of the F-test should be used in both the linear and nonlinear models.

When the thresholds $s_{1}$ and $s_{2}$ are unknown, they can be consistently estimated using a grid search over the values of $\triangle \operatorname{lnRER}$, after removing the $15 \%$ extreme observations. The optimal threshold values are selected by minimizing the sum of squared residuals of the OLS regression of the threshold asymmetric ARDL model. Once the nonlinear ARDL model is estimated and cointegration is established, we test for symmetry in the real exchange and the trade balance nexus by means of Wald tests: 1) long-run symmetry has the null hypothesis $\delta_{2}=$ $\delta_{3}=\delta_{4}$ and 2) short-run symmetry has the null hypothesis $\phi_{2 j}=\phi_{3 j}=\phi_{4 j}$, for all $j$. If the null hypotheses are rejected, then the model is asymmetric. There may be short-run asymmetry, long-run asymmetry or both short and long run asymmetries in the response of the trade balance to the real exchange rate. Given that the thresholds are not identified under the null hypotheses, the Wald statistic testing for symmetry follow a nonstandard distribution (Hansen, 1996). For this reason, their appropriate $p$-values are obtained by means of bootstrap procedure.

\section{Results and Discussion}

The empirical analysis begins with determination of the order of integration of the variables by means of unit root tests. This step is necessary to ascertain that none of the variables is integrated of order 2. For this purpose, two unit root tests are used: the PP test of (Phillips \& Perron, 1988) and the DF-GLS test suggested by (Elliott, et al. 1996). The tests are done both in the level and first difference of the variables and the results are presented in Table 2. Both tests are conclusively in favor of unit root for all variables in levels. However, when applied to the first differences, the null hypothesis of unit root is rejected. These findings suggest that all variables are non-stationary in the level and stationary in the first difference, implying that they are $\mathrm{I}(1)$ processes.

After checking the stationarity of the series, the next step is devoted to cointegration analysis and estimation of the short and long run dynamics of the trade balance model. Table 3 displays the results of the bounds testing for asymmetric cointegration and the estimated threshold nonlinear model. The Table also reports the results of the Wald test for detecting both the short and long run 
Table 2. Results of unit root tests.

\begin{tabular}{ccccc}
\hline \multirow{2}{*}{ Series } & \multicolumn{2}{c}{ Phillips-Perron } & \multicolumn{2}{c}{ PDF-GLS } \\
\cline { 2 - 5 } & $\mathrm{C}$ & $\mathrm{C} / \mathrm{T}$ & $\mathrm{C}$ & $\mathrm{C} / \mathrm{T}$ \\
\hline $\ln \mathrm{TB}$ & -2.182 & -3.274 & -1.746 & -3.164 \\
$\ln \mathrm{C}$ & 0.611 & -0.919 & 1.870 & -1.742 \\
$\ln \mathrm{RER}$ & -2.287 & -3.138 & $-2.293^{*}$ & -2.932 \\
$\Delta \ln \mathrm{TB}$ & $-7.722^{*}$ & $-8.163^{*}$ & $-5.850^{*}$ & $-6.832^{*}$ \\
$\Delta \ln \mathrm{Y}$ & $-4.376^{*}$ & $-4.748^{*}$ & $-2.843^{*}$ & $-3.784^{*}$ \\
$\Delta \operatorname{lnRER}$ & $-6.940^{*}$ & $-6.864^{*}$ & $-7.018^{*}$ & $-7.027^{*}$ \\
\hline
\end{tabular}

Note: TB, Y, and RER denote trade balance, real GDP, and real effective exchange rate, respectively. The optimal lag structure of the PP test is chosen based on the Newey-West bandwidth with Bartlett weights. The optimal lag structure of the DF-GLS test is chosen based on the Schwarz Information Criterion. The 5\% critical values for the Phillips-Perron unit root tests are -2.932 and -3.520 for models $\mathrm{C}$ and $\mathrm{C} / \mathrm{T}$ respectively. Those for the DF-GLS test are -1.949 and -3.190 for models $\mathrm{C}$ and C/T, respectively. ${ }^{*}$ denotes rejection of the null hypothesis of unit root at the $5 \%$ level.

Table 3. Estimates from threshold nonlinear ARDL model.

\begin{tabular}{|c|c|c|c|c|c|}
\hline \multicolumn{6}{|c|}{ Panel A: Long-run coefficient estimates } \\
\hline & $Y_{t}$ & $\mathrm{LPOS}_{\mathrm{t}}$ & $\mathrm{MED}_{\mathrm{t}}$ & $\mathrm{LNEG}_{\mathrm{t}}$ & D9 $94_{t}$ \\
\hline ARDL & $\begin{array}{l}-0.379^{*} \\
(-2.222)\end{array}$ & $\begin{array}{l}-1.480^{*} \\
(-3.642)\end{array}$ & $\begin{array}{c}0.637 \\
(0.515)\end{array}$ & $\begin{array}{l}-1.840^{*} \\
(-5.179)\end{array}$ & $\begin{array}{l}-0.438^{\star} \\
(-3.467)\end{array}$ \\
\hline FMOLS & $\begin{array}{l}-0.452^{\star} \\
(-5.555)\end{array}$ & $\begin{array}{l}-0.865^{\star} \\
(-5.205)\end{array}$ & $\begin{array}{c}0.444 \\
(0.658)\end{array}$ & $\begin{array}{l}-1.368^{\star} \\
(-8.846)\end{array}$ & $\begin{array}{l}-0.350^{*} \\
(-5.342)\end{array}$ \\
\hline DOLS & $\begin{array}{l}-0.522^{*} \\
(-4.061)\end{array}$ & $\begin{array}{l}-1.322^{\star} \\
(-5.357)\end{array}$ & $\begin{array}{l}0.7450 \\
(0.850)\end{array}$ & $\begin{array}{l}-1.846^{*} \\
(-8.258)\end{array}$ & $\begin{array}{l}-0.460^{*} \\
(-5.468)\end{array}$ \\
\hline \multicolumn{6}{|c|}{ Panel B: Short-run coefficient estimates } \\
\hline & $\Delta \mathrm{Y}_{\mathrm{t}}$ & $\Delta$ LPOS $_{\mathrm{t}}$ & $\triangle \mathrm{MED}_{\mathrm{t}}$ & $\Delta \mathrm{LNEG}_{\mathrm{t}}$ & $\mathrm{ECM}_{\mathrm{t}-1}$ \\
\hline Coefficient & $-0.624^{\star}$ & $-0.571^{\star}$ & $5.121^{\star}$ & $-1.203^{\star}$ & $-0.721^{\star}$ \\
\hline$t$-statistic & -2.870 & -2.263 & 3.100 & -6.905 & -6.663 \\
\hline \multicolumn{6}{|c|}{ Panel C: Threshold values } \\
\hline & $s_{1}=-0.802 \%$ & & & $\mathrm{~s}_{2}=2.029 \%$ & \\
\hline \multicolumn{6}{|c|}{ Panel D: Diagnostics } \\
\hline $\mathrm{F}$ & $\mathrm{R}^{2}$ & LM & LR & $\mathrm{W}_{\mathrm{SR}}$ & $\mathrm{W}_{\mathrm{LR}}$ \\
\hline $7.338^{\star}$ & 0.695 & $2.609[0.271]$ & $8.051[0.623]$ & $6.900^{*}[0.031]$ & $7.242^{*}[0.026]$ \\
\hline
\end{tabular}

Notes: The dependent variable is the trade balance (TB) defined as $\log (\mathrm{X} / \mathrm{M})$, where $\mathrm{X}$ and $\mathrm{M}$ are exports and imports, respectively. Y denotes domestic real income, LPOS, MED and LNEG denote large appreciation, medium change and large depreciation in the real effective exchange rate. ${ }^{*}$ and ${ }^{* *}$ indicate significance at the $5 \%$ and $10 \%$ levels, respectively. The model estimated is an $\operatorname{ARDL}(1,1,1)$ model. The upper bound critical value of the F-test for cointegration when there are two exogenous variables is 4.85 at the $5 \%$ level of significance. The comparable figures when $\mathrm{k}=4$ in the nonlinear model is -4.01 at the $5 \%$ level of significance. LM is the Lagrange multiplier statistic to test for autocorrelation of order two with $p$-value in brackets. LR is the Likelihood ratio statistic of Breusch-Pagan-Godfrey heteroskedasticity test with $p$-value in brackets. $\mathrm{W}_{\mathrm{SR}}$ denotes the Wald test for the short-run symmetry, which tests the null hypothesis that $\phi_{2 j}$ $=\phi_{3 \mathrm{j}}=\phi_{4 \mathrm{j}}$ in Equation (7). $\mathrm{W}_{\mathrm{LR}}$ refers to the Wald test for the long-run symmetry, which tests the null hypothesis that $\delta_{2}=\delta_{3}=\delta_{4}$ in Equation (7). The associated $p$-values are given in brackets. 
symmetry. The results of the ARDL bounds test for cointegration, as calculated by the F-statistic reported in Panel C, clearly reject the null hypothesis of no cointegration among the variables if we allow short run and long run asymmetry. This indicates the presence of a significant asymmetric long run relationship between trade balance, domestic income and real exchange rate. Further, the Wald test strongly rejects the null hypotheses of short and long-run symmetry. These results suggest that the nonlinear ARDL model combining both the short and long run asymmetry is suitable for this study.

The threshold values define three regimes, the upper regime or "large" appreciations (i.e. $\Delta \operatorname{lnRER} \mathrm{R}_{\mathrm{t}}>2.029 \%$ ), the central regime or "small" exchange rate changes (i.e. $-0.802 \% \leq \Delta \operatorname{lnRER} R_{t} \leq 2.029 \%$ ), and the lower regime or "large" depreciations (i.e. $\Delta \operatorname{lnRER} R_{t}<-0.802 \%$ ), covering $31 \%, 15 \%$ and $54 \%$ of the sample, respectively.

As cointegration exists among the variables, we further proceed with the estimation of the long-run coefficients associated with the explanatory variables. To that end, we employ the ARDL approach along with the Fully Modified OLS (FMOLS) and the Dynamic OLS (DOLS) estimators, which were used to check the robustness of the results. Let us first consider the long-run estimates reported in Panel A. The results indicate that the trade balance has a negative long-run relationship with real domestic income. This sign is what we would expect if demand is the driving force in determining imports. A $1 \%$ increase in domestic real income results in about $0.4 \%$ decrease in the trade balance in the long-run. Indeed, a rise in domestic income encourages households and private sector to demand more goods and services including imports, hence leading to a significant deterioration of the trade balance. This finding agrees with Genemo (2017) who found a negative relationship between domestic income and the trade balance in selected African countries. It is also consistent with Keho (2021a) who found a negative effect of domestic income on the trade balance in Cote d'Ivoire. Further, the results indicate a negative long-run relationship between the real exchange rate and the trade balance, as would be expected if a real depreciation of domestic currency stimulates exports and discourages imports. However, the response of the trade balance to the real exchange rate changes is asymmetric. The long-run response of the trade balance to a unit shock in the real exchange rate in the upper regime (i.e. $\Delta \operatorname{lnRER}_{\mathrm{t}}>2.029 \%$ ) is -1.4 , while in the lower regime (i.e. $\left.\Delta \operatorname{lnRER} R_{t}<-0.802 \%\right)$ it is -1.8 . In the central regime, the real exchange rate changes do not affect significantly the trade balance, confirming the existence of a "band of inaction" in the exchange rate pass-through to the trade balance. Consequently, our findings indicate that the trade balance responds stronger to large negative shocks in the real exchange rate (large depreciations) than to large positive ones (large appreciations).

With regard to the short-run results reported in Panel B, we observe that all variables have significant effects on the trade balance. Domestic income has a negative and significant relationship with the trade balance. This sign is what 
will be expected according to economic theory when the demand side dominates. Other things remain the same, a one percent increase in domestic income leads to about 0.624 percentage point decrease in the trade balance. As far as the real exchange rate is concerned, we note a similar pattern to that revealed in the extreme regimes in the long-run, that is, large depreciations of the real exchange rate are passed to the trade balance in a larger extent than large appreciations. More precisely, large depreciations of the real exchange rate improve the trade balance by $1.203 \%$, while large appreciations worsen the trade balance by $0.571 \%$. However, we note a different effect at work in the central regime where we find a significant positive short-run relationship between the real exchange rate and the trade balance. This suggests that in the central regime, small changes in the real exchange rate are associated with improvement in the trade balance in the shortrun. The coefficient on the lagged error term is negatively signed and statistically significant. This provides additional evidence of the presence of a long-run relationship among the variables.

\section{Conclusion}

This paper re-examines the effect of the real exchange rate on the trade balance in Cote d'Ivoire. Previous studies on this issue relied on linear models in which real exchange rate depreciation and depreciation have the same effect, in absolute value, on the trade balance. A growing body of empirical studies employed the nonlinear autoregressive distributed lag approach inspired by (Shin et al., 2014) to examine the relationship between real exchange rate and trade balance. This approach filters real exchange rate appreciations from depreciations and estimates their respective effects on the trade balance. However, such a method assumes a zero threshold effect depending on the direction of the change in exchange rate, ignoring the size effect of changes in real exchange rate. This study contributes to the existing literature by investigating the nonlinear effects of real exchange rate on the trade balance in Cote d'Ivoire. By relying on the concept of partial sum, we decompose the movement in the real effective exchange rate into large depreciations, large appreciations and small changes. We then estimate a threshold nonlinear ARDL model in which the regime transition is governed by the sign and size of the real exchange rate growth. The extended model was estimated using the ARDL, FMOLS and DOLS methods and annual data covering the period 1975-2017.

The cointegration test confirms the existence of a long-run relationship between the real exchange rate, gross domestic income and the trade balance. Gross domestic income has a negative relationship with the trade balance which shows that increase in domestic income leads to a reduction in the trade balance. Thus, economic growth is playing a significant role in reducing the trade balance in Cote d'Ivoire both in the short and long-run.

The results confirm that exchange rate movements have significant short-run and long-run effects on the trade balance in Cote d'Ivoire. Namely, exchange 
rate changes are negatively associated with the trade balance both in the long and short-run, suggesting that real depreciation of domestic currency improves the trade balance while real appreciation worsens it. Therefore, our results do not support the evidence of the short-run worsening of trade balance suggested by the J-curve effect. We found that large depreciations are passed to the trade balance in a larger extent than large appreciations. This confirms that the trade balance responds asymmetrically to the real exchange rate. Our findings also suggest that in monitoring the exchange rate movements, attention should not only be focused on large changes but also on relatively small changes. On the other hand, as economic growth reduces the trade balance, the country should implement economic policies that focus on the production of imported-substituted goods. Import-substitution policies will help to mitigate the deterioration in the trade balance caused by real exchange rate appreciation.

This study is not free of shortcomings. First, the study uses aggregate trade balance of Cote d'Ivoire with the rest of the world. As Cote d'Ivoire has different export and import prices with its trade partners, the results may suffer from aggregation bias. Therefore, future research should be done at disaggregated level using the bilateral trade balance of Cote d'Ivoire with its major trade partners. Second, it may be promising to examine the exchange rate and trade balance relationship at commodity level. We intend to investigate these lines of research in future works.

\section{Conflicts of Interest}

The author declares no conflicts of interest regarding the publication of this paper.

\section{References}

Adeniyi, O., Omisakin, O., \& Oyinlola, A. (2011). Exchange Rate and Trade Balance in West African Monetary Zone: Is There a J-Curve? The International Journal of Applied Economics and Finance, 5, 167-176. https://dx.doi.org/10.3923/ijaef.2011.167.176

Akoto, L., \& Sakyi, D. (2019). Empirical Analysis of the Determinants of Trade Balance in Post-liberalization Ghana. Foreign Trade Review, 54, 177-205. https://doi.org/10.1177\%2F0015732519851632

Akpansung, A. O., \& Babalola, S. J. (2013). Effects of Real Exchange Rate on Trade Balance: Empirical Evidence from Nigeria. Asian Journal of Empirical Research, 3, 605-617.

Anning, L., Riti, J. S., \& Yapatake, K. T. (2015). Exchange Rate and Trade Balance in Ghana-Testing the Validity of the Marshall-Lerner Condition. International Journal of Development and Emerging Economics, 3, 38-52.

Arize, A. C., Malindretos, J., \& Igwe, E. U. (2017). Do Exchange Rate Changes Improve the Trade Balance: An Asymmetric Nonlinear Cointegration Approach. International Review of Economics \& Finance, 49, 313-326. https://doi.org/10.1016/j.iref.2017.02.007

Baharumshah, A. (2001). The Effect of Exchange Rate on Bilateral Trade Balance: New Evidence from Malaysia and Thailand. Asian Economic Journal, 15, 291-312.

https://doi.org/10.1111/1467-8381.00135 
Bahmani-Oskooee, M. (2001). Nominal and Real Effective Exchange Rates of Middle Eastern Countries and Their Trade Performance. Applied Economics, 33, 103-111. https://doi.org/10.1080/00036840122490

Bahmani-Oskooee, M., \& Arize, A. C. (2019). U.S.-Africa Trade Balance and the J-Curve: An Asymmetry Analysis. The International Trade Journal, 33, 322-343. https://doi.org/10.1080/08853908.2019.1570881

Bahmani-Oskooee, M., \& Arize, A. C. (2020). Asymmetry Cointegration and the J-Curve: New Evidence from Africa. Journal of Economic Studies, 47, 969-984. https://doi.org/10.1108/JES-09-2018-0333

Bahmani-Oskooee, M., \& Baek, J. (2019). Asymmetry Cointegration and the J-Curve: New Evidence from Korean Bilateral Trade Balance Models with her 14 Partners. Journal of the Asia Pacific Economy, 24, 66-81. https://doi.org/10.1080/13547860.2018.1469589

Bahmani-Oskooee, M., \& Fariditavana, H. (2015). Nonlinear ARDL Approach, Asymmetric Effects and the J-Curve. Journal of Economic Studies, 42, 519-530.

https://doi.org/10.1108/JES-03-2015-0042

Bahmani-Oskooee, M., \& Fariditavana, H. (2016). Nonlinear ARDL Approach and the J-Curve Phenomenon. Open Economies Review, 27, 51-70. https://doi.org/10.1007/s11079-015-9369-5

Bahmani-Oskooee, M., \& Fariditavana, H. (2020). Asymmetric Cointegration and the J-Curve: New Evidence from Commodity Trade between the U.S. \& Canada. International Economics and Economic Policy, 17, 427-482.

https://doi.org/10.1007/s10368-019-00447-0

Bahmani-Oskooee, M., \& Gelan, A. (2020). The South Africa-U.S. Trade and the Real Exchange Rate: Asymmetric Evidence from 25 Industries. South African Journal of Economics, 88, 186-203. https://doi.org/10.1111/saje.12242

Bahmani-Oskooee, M., Bose, N., \& Zhang, Y. (2019). An Asymmetric Analysis of the J-Curve Effect in the Commodity Trade between China and the US. The World Economy, 42, 2854-2899. https://doi.org/10.1111/twec.12829

Boyd, D., Caporale, G. M., \& Smith, R. (2001). Real Exchange Rate Effects on the Balance of Trade: Cointegration and the Marshall-Lerner Condition. International Journal of Finance and Economics, 6, 187-200. https://doi.org/10.1002/ijfe.157

Bussière, M. (2013). Exchange Rate Pass-through to Trade Prices: The Role of Nonlinearities and Asymmetries. Oxford Bulletin of Economics and Statistics, 75, 731-758. https://doi.org/10.1111/j.1468-0084.2012.00711.x

Caporale, G. M., Gil-Alana, L., \& Mudida, R. (2015). Testing the Marshall-Lerner Condition in Kenya. South African Journal of Economics, 83, 253-268. https://doi.org/10.1111/saje.12052

Davies, R. B. (1987). Hypothesis Testing when a Nuisance Parameter is Present only under the Alternative. Biometrika, 74, 33-43. https://doi.org/10.1093/biomet/74.1.33

Duasa, J. (2007). Determinants of Malaysian Trade Balance: An ARDL Bound Testing Approach. Global Economic Review, 36, 89-102.

https://doi.org/10.1080/12265080701217405

Elliott, G., Rothenberg, T. J., \& Stock, J. H. (1996). Efficient Tests for an Autoregressive Unit Root. Econometrica, 64, 813-836. https://doi.org/10.2307/2171846

Genemo, K. B. (2017). Effect of Exchange Rate on Trade Balance in Major East African Countries: Evidence from Panel Cointegration. European Business and Management, 3, 95-104. https://doi.org/10.11648/j.ebm.20170306.11 
Gonzalo, J. (1994). Five Alternative Methods of Estimating Long-Run Equilibrium Relationship. Journal of Econometrics, 60, 203-233. https://doi.org/10.1016/0304-4076(94)90044-2

Hansen, B. (1996). Inference When a Nuisance Parameter Is Not Identified under the Null Hypothesis. Econometrica, 64, 413-430. https://doi.org/10.2307/2171789

Hatemi-J, A., \& Irandoust, M. (2005). Bilateral Trade Elasticities: Sweden versus Her Trade Partners. American Review of Political Economy, 3, 38-50.

Hunegnaw, F. B., \& Kim, S. (2017). Foreign Exchange Rate and Trade Balance Dynamics in East African Countries. The Journal of International Trade \& Economic Develop ment, 26, 979-999. https://doi.org/10.1080/09638199.2017.1327611

Igue, N. N., \& Ogunleye, T. S. (2014). Impact of Real Exchange Rate on Trade Balance in Nigeria. African Development Review, 26, 347-3578. https://doi.org/10.1111/1467-8268.12086

Inder, B. (1993). Estimating Long-Run Relationships in Economics: A Comparison of Different Approaches. Journal of Econometrics, 57, 53-68. https://doi.org/10.1016/0304-4076(93)90058-D

Iyke, N. B., \& Ho, S. Y. (2017). The Real Exchange Rate, the Ghanaian Trade Balance, and the J-Curve. Journal of African Business, 18, 380-392. https://doi.org/10.1080/15228916.2017.1315706

Kale, P. (2001). Turkey's Trade Balance in the Short and the Long Run: Error-Correction Modeling and Cointegration. The International Trade Journal, 15, 27-56. https://doi.org/10.1080/088539001300005440

Kamugisha, G., \& Assoua, J. E. (2020). Effects of a Devaluation on Trade Balance in Uganda: An ARDL Cointegration Approach. International Journal of Economics and Finance, 12, 42-53. https://doi.org/10.5539/ijef.v12n7p42

Karoro, T. D., Aziakpono, M. J., \& Cattaneo, N. (2009). Exchange Rate Pass-Through to Import Prices in South Africa: Is There Asymmetry? South African Journal of Economics, 77, 380-398. https://doi.org/10.1111/j.1813-6982.2009.01216.x

Keho, Y. (2021a). Real Exchange Rate and Trade Balance Dynamics in Cote d'Ivoire. International Journal of Economics and Financial Issues, 11, 61-70. https://doi.org/10.32479/ijefi.10857

Keho, Y. (2021b). Asymmetric Effects of Real Exchange Rate on Trade Balance in Cote d'Ivoire: Evidence from Nonlinear ARDL Approach. Applied Economics and Finance, 8, 9-21. https://doi.org/10.11114/aef.v8i3.5216

Lal, A., \& Lowinger, T. (2002). The J-Curve: Evidence from East Asia. Journal of Economic Integration, 17, 397-415. https://doi.org/10.11130/jei.2002.17.2.397

Loto, M. A. (2011). Does Devaluation Improve the Trade Balance of Nigeria? A Test of the Marshall Lerner Condition. Journal of Economics and International Finance, 3, 624-633.

Magee, S. P. (1973). Currency Contracts, Pass Through, and Devaluation. Brookings Papers of Economic Activity, 1973, 303-325. https://doi.org/10.2307/2534091

Meniago, C., \& Eita, J. H. (2017). The Effects of Exchange Rate Changes on Sub-Saharan Africa Trade. International Journal of Sustainable Economy, 9, 213-230. https://doi.org/10.1504/IJSE.2017.085065

Musila, J. W., \& Newark, J. (2003). Does Currency Devaluation Improve the Trade Balance in the Long Run? Evidence from Malawi. African Development Review, 15, 339-352. https://doi.org/10.1111/j.1467-8268.2003.00076.x 
Nathaniel, S. P. (2020). Does Exchange Rate Have Asymmetric Impact on Trade Balance? Fresh Insights from Combined Cointegration. Studies in Business and Economics, 15, 259-269. https://doi.org/10.2478/sbe-2020-0019

Ogbonna, B. C. (2016). Trade Balance Effect of Exchange Rate Devaluation in Benin Republic: The Empirical Evidence. IOSR Journal of Economics and Finance, 7, 33-43.

Onafowora, O. (2003). Exchange Rate and Trade Balance in East Asia: Is there a J-curve. Economics Bulletin, 5, 1-13.

Ousseini, A. M., Hu, X. J., \& Aboubacar, B. (2017). WAEMU Trade and Current Account Balance Deficit Analysis: A Panel VAR Approach. Theoretical Economics Letters, 7, 834-861. https://doi.org/10.4236/tel.2017.74060

Pesaran, M. H., Shin, Y., \& Smith, R. J. (2001). Bounds Testing Approaches to the Analysis of Level Relationships. Journal of Applied Econometrics, 16, 289-326. https://doi.org/10.1002/jae.616

Phillips, P. C. B., \& Perron, P. (1988). Testing for a Unit Root in a Time Series Regression. Biometrika, 75, 335-346. https://doi.org/10.1093/biomet/75.2.335

Shawa, M. J., \& Shen, Y. (2013). Analysis of the Determinants of Trade Balance: Case Study of Tanzania. International Journal of Business and Economics Research, 2, 134-141. https://doi.org/10.11648/j.ijber.20130206.13

Shin, Y., Yu, B., \& Greenwood-Nimmo, M. (2014). Modelling Asymmetric Co-integration and Dynamic Multipliers in a Nonlinear ARDL Framework. In W. Horrace, \& R. Sickles (Eds.), Festchrift in Honor of Peter Schmidt: Econometric Methods and Applications (pp. 281-314). New York, NY: Springer. https://doi.org/10.1007/978-1-4899-8008-3_9

Sokeng Dongfack, L. P., \& Ouyang, H. (2019). The Impact of Real Exchange Rate Depreciation on Cameroon's Trade Balance: Is Devaluation a Remedy for Persistent Trade Deficits? Journal of Economic Integration, 34, 189-213. https://doi.org/10.11130/jei.2019.34.1.189

Yazgan, M. E., \& Ozturk, S. S. (2019). Real Exchange Rates and the Balance of Trade: Does the J-Curve Effect Really Hold? Open Economies Review, 30, 343-373. https://doi.org/10.1007/s11079-018-9510-3

Yol, M. A., \& Baharumshah, A. Z. (2007). Estimating Exchange Rate and Bilateral Trade Balance Relationships: The Experience of Sub-Saharan African Countries. South African Journal of Economics, 75, 35-51. https://doi.org/10.1111/j.1813-6982.2007.00104.x 